\title{
鉄筋コンクリート柱梁接合部：終局強度と部材端力の相互作用 REINFORCED CONCRETE BEAM-COLUMN JOINT : INTERACTION OF ULTIMATE STRENGTHS AND FORCES AT MEMBER ENDS
}

\author{
塩原 等* \\ Hitoshi SHIOHARA
}

\begin{abstract}
The author proposed a new mathematical model which predicts the ultimate behavior of two-dimensional reinforced concrete beam-column joints. The model is based on a kinematic model named nine DOF model combined with non-linear biaxial constitutive relation of concrete and steel to bear simple algebraic expressions for the ultimate moment capacity and moment at balanced failure. It is applicable to symmetric interior beam-column joints subjected four symmetric moments transmitted among the four adjacent members. This paper extends the model such that it could consider the interaction of ultimate strength and axial force, shear force transmitted from adjacent members framed into the joint as well as the amount of joint shear reinforcement in a beam-column joint designed by weak beam-strong column concept for Capacity Design. It is concluded from the theory that the factors increasing the moment capacity of beam-column joints include (1) axial force, (2) margin of moment capacity of column to beam, (3) confinement by joint shear reinforcement, (4) confinement by mid-layer bars in columns, the effect of which are followed by a simple combination rule in a simple algebraic equation form. It is also shown that the theory predicts that the factorsabove have little effect on the moment at balanced failure while (5) the concrete strength and (6) the ratio of the bar distance to the depth of member have large effect.
\end{abstract}

Keywords : reinforced concrete, beam-column joint, algebraic expression, ultimate moment, balanced failure, axial force, shear force, joint shear reinforcement 鉄筋コンクリート，柱梁接合部，代数式，終局モーメント，釣合い破壊，軸力，せん断力，接合部補強筋

1. 序

鉄筋コンクリート造モーメント骨組構造の柱梁接合部の強度や損 傷集中などの特性は，部材の軸力，柱梁接合部に接続する部材のせん 断力，接合部補強量，通し主筋の付着性能，主筋位置などの影響を受 けると考えられる。これまで多くの柱梁接合部架構の実験的研究が実 施され，これらの影響が検討されてきた12)3)4)5)。ある研究では，柱 の圧縮軸力や接合部横補強筋量は柱梁接合部の強度への影響は少な いとするものがある一方で, 別の研究では, 柱梁接合部の損傷の進行 に影響を及ぼしたとするものもあり，それらの結論は一見矛盾してい るように見える。しかし実際には多くの因子が相互に影響しているの で，実験的検討によりそれらの影響を定量化することには自ずと限界 があり，現行の耐震設計法では，設計に部材軸力や接合部補強量の影 響，主筋位置の影響は反映されていない。

さらにこれらに加えて柱梁接合部の特性は，接続する部材の曲げ降 伏によっても影響を受けると考えられる。梁降伏型に設計された架構 では，柱梁接合部に接続する部材の一部の主筋が部材端で降伏し，層 間変形が増大するにつ柱梁接合部がせん断破壊する現象が存在す る。これは接続する部材の曲げ降伏が接合部の強度を低下させている ことになる。しかしこの現象は設計の限界変形の中では起こらないと いう理由で必ずしも耐震設計には反映されていない。しかし，草苅·

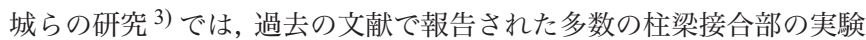
結果を分析して, 梁の曲げ降伏後に接合部がせん断破壊した場合の梁 の終局曲げ強度は, 接合部が梁曲げ降伏後にせん断破壞しない場合と
比較して相対的に低いと述べている。ニュージーランドの Park ら 6) は，柱梁接合部の通し主筋の付着劣化は，圧縮鉄筋の圧縮応力分担を 減少させ，梁端部危険断面の曲げ強度の低下を起こさせ，架構の耐力 を低下させることを指摘した。つまり，接続する部材の応力や降伏が 接合部の強度に影響を及ぼす一方で，接合部の存在自体がまた部材の 強度に影響を及ぼしている。

このように，柱梁接合部の特性と部材の強度には切り離して説明で きない相互作用が存在する。しかし, 既往の実験的研究では, 柱梁接 合部の強度と部材の強度は独立であるという仮説に立って実験デー 夕を整理せざるを得ないという方法論の限界からその相互作用は断 片的に指摘されているにすぎず, 体系的な解明はされていない。また, 既往の力学モデルによる研究においても，このような相互作用を定量 的に予言してその予測を実験で検証して耐震設計に供することので きるような設計法を提案した研究は未だ存在していない。

本報告では，そのような柱梁接合部と接続する部材の相互作用を定 量化する力学モデルと, 耐震設計に供することのできる数式表現を提 案する。ここで用いる力学モデルは，接合部のせん断破壊は接合部の せん断抵抗機構の破壊であるという仮説に立脚した従来の見解とは 立場を異にしている。すなわち，柱梁接合部の破壊は，柱梁接合部の せん断力抵抗機構が健全に保持されたままで, 柱梁接合部内で通し主 筋が引張降伏し，あるいは主筋の弾性伸びが増大して，柱梁接合部内 でコンクリートのひび割れが拡大して, 柱梁接合部の変形が増大し, 損傷の集中が起こるという事実に適合するように構築され，筆者が文

\footnotetext{
* 東京大学大学院工学系研究科 准教授. 工博

Assoc. Prof., Graduate School of Engineering, The University of Tokyo, Dr. Eng.
} 

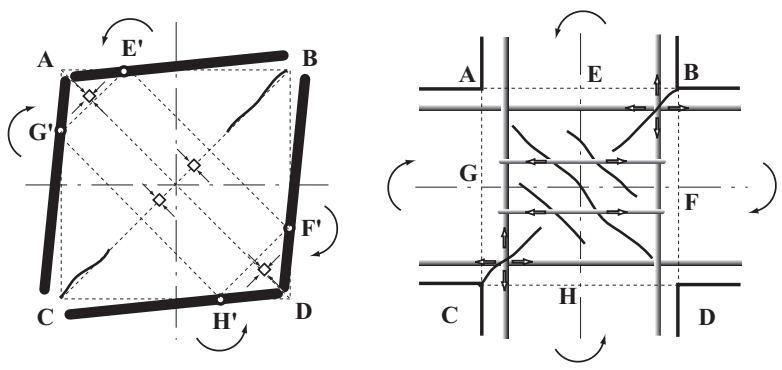

図 1 ひび割れ発生後の斜め圧縮束の形成と補強筋の引張力の発 生 ${ }^{7)}$

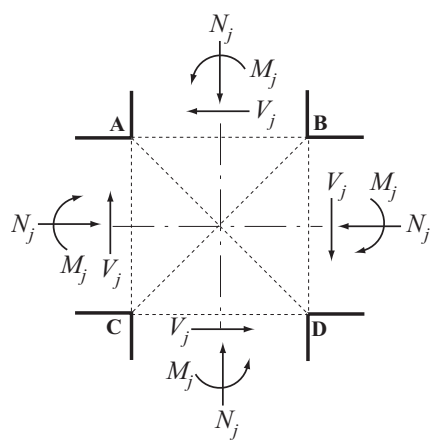

図 2 柱梁接合部に働く外力: モーメント $M_{j}$ 軸力 $N_{j}$ とせん断力 $V_{j}$

献 7 で提案した 9 自由度モデルに基づいている（図 1)。すなわち, 本 報告は, 文献 7 の柱梁接合部の基本構成式に基づき柱梁接合部の終局 強度の数式解を論じた報告の続編である。本論文の目的は，その力学 モデルを展開・拡張して, 接続する部材から柱梁接合部に接合部に作 用する軸力・せん断力などの外部作用力や接合部横補強筋や柱中段筋 による受動的拘束力などが, 梁曲げ降伏型に設計された柱梁接合部に おいて, 接合部の終局強度 7), 接合部の釣合い破壞 7) および限界補強 量 7)に及ぼす効果と, それらの間の相互作用の数式的表現を提案し, その妥当性を検討することである。

2. 柱梁接合部の終局モーメントと部材軸力や部材せん断力との相 互作用

\section{1 柱梁接合部の終局状態}

本論文では，拙著の文献 7) と同様に，柱梁接合部に次のような終局 状態を想定する。鉄筋コンクリートの柱梁接合部は, 一様にせん断変 形が生じるパネルとしてよりは，柱端部と梁端部の拘束を考慮して 4 枚の剛板に囲まれた領域内での変形としてモデル化することが妥当 である。部材端からモーメントを受ける十字型柱梁接合部では, 4 枚 の剛板の回転量が逆対称に分布することから, 接合部内に分布する主 歪の方向は部材軸と 45 度の角度をなす対角線方向となる。

剛板の回転が増大すると, ひび割れ後のコンクリートの異方性に よって, ひび割れに直交する方向にコンクリートは引張力を負担しな くなり, ひび割れを横切る柱梁の通し主筋や接合部内の補強筋に引張 力が再分配される。剛板の回転変形が増大すると歪の増大するコンク リートの斜め压縮束の中央付近でコンクリートの圧壊が生じて終局 状態に達する。このような応力伝達機構における柱梁接合部の終局

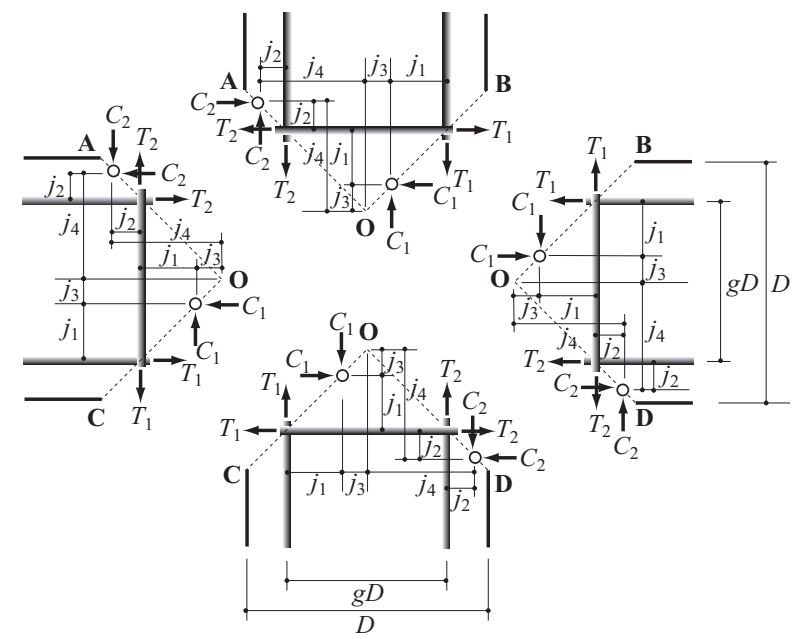

図 3 十字型柱梁接合部の内部応力とその作用位置 ${ }^{7)}$

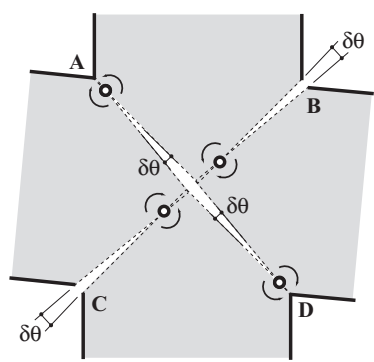

図 4 仮想変位 ${ }^{7)}$

モーメントは, 力の釣合い条件，終局時のコンクリートの破壊条件と 鉄筋の降伏条件から導かれる。

\section{2 柱梁接合部の終局モーメント}

本論文で対象とする柱梁接合部の形状は, 文献 7) と同様に, 柱せい と梁せいが $D$ で等しい正方形であるものとする。また，柱幅と梁幅 は共通で $b$ とする。接合部の補強筋は, 通し主筋が接合部内を縦横に 貫通する通し配筋とする。柱梁それぞれの部材断面において, 主筋は, 上端と下端に対称に配置される。それらの主筋位置の間隔距離は，部 材せい $D$ の 倍すなわち $g D$ であるものとする。以下, 本論文では係 数 $g$ を「主筋間隔比 ${ }^{7)} 」$ と定義する。部材断面の中央に通し主筋が集 中して配置されている場合には, 主筋間隔比 $g$ はゼロである。柱梁接 合部の終局モーメントの算定にあたって, 鉄筋は軸方向力のみを伝達 し, その応力度は降伏点 $f_{y}$ を超えない弾塑性材料とする。コンクリー 卜の圧縮強度は $f_{c}^{\prime}$ であり, 引張力は負担しないものとする。

文献 7 では, 柱梁接合部に㗢く外力をモーメントに限定した場合の 終局モーメント式を示した。本論文では，モーメントに加えて，図 2 のように軸力とせん断力が同時に作用した場合の終局モーメントを 検討する。設定する十字型柱梁接合部の内部応力の大きさを表す記号 は図 3 に示すものとする。一般に柱梁接合部に作用する直応力の要因 には，重力による柱の軸力や地震力により生じる柱の変動軸力，内力 として作用するプレストレスカなどがある。さらに，接合部の変形の 増大につれて接合部が縦横に膨張するために, 接合部を通過する主筋 や，接合部内にのみに配置される横補強筋に引張力が働くことにより 
その反力として受動的にコンクリートを拘束する力が生じる。そこ で，これらを図 2 に示すように，柱心と梁心から対称な軸力（圧縮 正） $N_{j}$ として単純化して考慮する。さらに, 柱や梁のせん断力として 接合部に作用するせん断力を対称なせん断力 $V_{j}$ として考慮する。軸 力 $N_{j}$ ならびにせん断力 $V_{j}$ の作用線は, すべて柱梁接合部の中心 $\mathrm{O}$ 点 を通るものとする。

接合部を対角線で分割した 4 つのフリーボディに, 図 4 に示した仮 想変位を与えて仮想変位の原理を適用して, 一定の軸力 $N_{j}$ および $V_{j}$ の作用する条件での, 柱梁接合部の終局モーメント $M_{j u}$ および柱梁接 合部の釣合いモーメント $M_{j b}$ を導く。導出にあたっては, 文献 7 とは 異なり, 応力 $N_{j}$ と $V_{j}$ のなす仮想仕事も考える必要があることから, 文献 7 で導入された応力中心間距離 $j_{1}$ および $j_{2}$ に加えて, 応力 $V_{j}$ と $N_{j}$ の作用線が通っているものと考えている接合部中心の 0 から, コン クリートの圧縮合力 $C_{1}$ からまでの距離を表す $j_{3}$ ならびに, 接合部中 心の $\mathbf{O}$ 点からコンクリートの圧縮合力 $C_{2}$ からまでの距離を表す $j_{4}$ を 導入する。図 3 に, $j_{3}$ と $j_{4}$ が示してある。压縮ゾーンにおける圧縮歪 度の分布は，ほぼ比例的に変化するものと近似して，古典的曲げ理論 におけるストレスブロックの考え方を準用して圧縮力の分布形状を 定めることができるものとする。すなわち，ストレスブロックの形状 を表す係数 $\beta_{3}$ とし, ストレスブロックのコンクリートの応力度と, コ ンクリート圧縮強度 $f_{c}^{\prime}$ の比を表す。

モーメント $M_{j}$ のなす仮想仕事は, $2 M_{j} \delta \theta$ となる。また, 軸力 $N_{j}$ お よびせん断力 $V_{j}$ のなす仮想仕事は, それぞれ, $2 N_{j}\left(j_{4}-j_{3}\right) \delta \theta$ および $2 V_{j}\left(j_{4}+j_{3}\right) \delta \theta$ となる。さらに, 接合部を通過する通し主筋がなす内 部仮想仕事は, $4\left(j_{1} T_{1}+j_{2} T_{2}\right)$ である。よって, 外部仮想仕事と内部仮 想仕事は等しいことから, 接合部の抵抗モーメント $M_{j}$ は, 次式で表 される。

$$
M_{j}=2\left(j_{1} T_{1}+j_{2} T_{2}\right)+\left(-j_{3}+j_{4}\right) N_{j}+\left(j_{3}+j_{4}\right) V_{j}
$$

ここに，応力中心間距離は $j_{1}, j_{2}, j_{3}$ および, $j_{4}$ は,

$$
j_{1}=\frac{1}{2} D\left(g-\frac{T_{1}+\frac{1}{2} N_{j}-\frac{1}{2} V j}{b D \beta_{3} f_{c}^{\prime}}\right)
$$

$$
j_{2}=\frac{1}{2} D\left((1-g)-\frac{T_{2}+\frac{1}{2} N_{j}+\frac{1}{2} V j}{b D \beta_{3} f_{c}^{\prime}}\right)
$$

$$
j_{3}=\frac{1}{2} g D-j_{1}=\frac{1}{2} D\left(\frac{T_{1}+\frac{1}{2} N_{j}-\frac{1}{2} V j}{b D \beta_{3} f_{c}^{\prime}}\right)
$$

$$
j_{4}=\frac{1}{2} g D+j_{2}=\frac{1}{2} D\left(1-\frac{T_{2}+\frac{1}{2} N_{j}+\frac{1}{2} V j}{b D \beta_{3} f_{c}^{\prime}}\right)
$$

となる。ここで, 接合部内を貫通する主筋の引張側の対角線を横切る 応力 $T_{1}$ と圧縮側の応力 $T_{2}$ の比の值を $\alpha$ (以下, 「接合部内主筋応力 比」）と定義することとする ${ }^{7)}$ 。こで, $T_{1}=T, T_{2}=\alpha T$ をそれぞ れ, 式(2)から式 (5) までに代入し, それらを式(1) に代入して整理す ると, 主筋応力 $T$ と柱梁接合部の抵抗モーメント $M_{j}$ の関係を表す式 (6) が得られる。

$$
\begin{aligned}
M_{j}= & D T\left\{\alpha+g(1-\alpha)-\frac{\left(1+\alpha^{2}\right) T}{b D \beta_{3} f_{c}^{\prime}}\right\}+\frac{1}{2} D\left(N_{j}+V_{j}\right) \\
& -\frac{1}{2} D \frac{N_{j}^{2}+V_{j}^{2}}{b D \beta_{3} f_{c}^{\prime}}-D T \frac{(1+\alpha) N_{j}-(1-\alpha) V_{j}}{b D \beta_{3} f_{c}^{\prime}}
\end{aligned}
$$

以下，通し主筋の鉄筋応力比 $\alpha$ がゼロの場合を接合部 I，通し主筋 の鉄筋応力比 $\alpha$ が 1 の場合を接合部 II と定義する ${ }^{7)}$ 。接合部内主筋応 力比 $\alpha$ につて（接合部 I）と（接合部 II）の場合について，それぞ れ, 主筋応力 $T$ が降伏強度 $T_{y}$ に達したものとして, $T$ に $T_{y}$ を代入し て，接合部 I と接合部 II について，それぞれ簡略化した柱梁接合部の 終局モーメント $M_{j u}$ を表す式(7)と(8)が得られる。

$$
\begin{aligned}
M_{j u}= & D T_{y}\left\{g-\frac{T_{y}}{b D \beta_{3} f_{c}^{\prime}}\right\}+\frac{1}{2} D\left(N_{j}+V_{j}\right)-\frac{1}{2} D \frac{N_{j}^{2}+V_{j}^{2}}{b D \beta_{3} f_{c}^{\prime}} \\
& -D T_{y} \frac{N_{j}-V_{j}}{b D \beta_{3} f_{c}^{\prime}}(\text { 接合部 I }) \\
M_{j u}= & D T_{y}\left\{1-\frac{2 T_{y}}{b D \beta_{3} f_{c}^{\prime}}\right\}+\frac{1}{2} D\left(N_{j}+V_{j}\right)-\frac{1}{2} D \frac{N_{j}^{2}+V_{j}^{2}}{b D \beta_{3} f_{c}^{\prime}} \\
& -D T_{y} \frac{2 N_{j}}{b D \beta_{3} f_{c}^{\prime}} \quad(\text { 接合部 II })
\end{aligned}
$$

2. 3 柱梁接合部の終局曲げモーメントにおける軸力・せん断力の 影響

部材端部から柱梁接合部に作用する力である軸力 $N_{j}$ とせん断力 $V_{j}$ が，柱梁接合部の終局曲げモーメントに及ぼす効果を評価する。柱梁 接合部の終局モーメント $M_{j u}$ を表す式 (7)もしくは式(8)において, 軸 力 $N_{j}$ およびせん断力 $V_{j}$ をゼロとおいた場合の柱梁接合部の終局モー メント $M_{j u}$ からの増加量 $\Delta M_{j u}$ が求められる。それらは, 式 (7)もし くは式 (8)の第 2 項目以降であり, 次式で表される。

$$
\Delta M_{j u}=\frac{1}{2} D\left(N_{j}+V_{j}\right)-\frac{1}{2} D \frac{N_{j}^{2}+V_{j}^{2}}{b D \beta_{3} f_{c}^{\prime}}-D T_{y} \frac{N_{j}-V_{j}}{b D \beta_{3} f_{c}{ }^{\prime}}
$$

( 接合部 I )

$$
\Delta M_{j u}=\frac{1}{2} D\left(N_{j}+V_{j}\right)-\frac{1}{2} D \frac{N_{j}^{2}+V_{j}^{2}}{b D \beta_{3} f_{c}^{\prime}}-D T_{y} \frac{2 N_{j}}{b D \beta_{3} f_{c}{ }^{\prime}}
$$

( 接合部 II ) 
柱梁接合部での主筋降伏時の応力 $T_{y}$, 軸力 $N_{j}$ およびせん断力 $V_{j}$ と $b D \beta_{3} f_{c}^{\prime}$ の比がそれぞれ 1.0 に比べて相対的に小さいものとして, こ れらの項を無視して近似すれば, 柱梁接合部の終局モーメント $M_{j u}$ の 増分 $\Delta M_{j u}$ は，接合部 I と接合部 II の 2 つの対照的な場合についてい ずれも，同じ次の近似式で表すことができる。

$$
\Delta M_{j u} \cong \frac{1}{2} D N_{j}+\frac{1}{2} D V_{j}
$$

すなわち, 柱梁接合部の終局モーメントは, 軸力 $N_{j}$ およびせん断 力 $V_{j}$ の効果によって増加し, その増分は, 式 (11) で評価できる。た だし, 精解である式 (9) および式 (10) からわかるように, 主筋の降伏 時の応力 $T_{y}$ や軸力 $N_{j}$ が大きいと接合部モーメントの増加は式(11)よ りは小さくなる頭打ち傾向を示す。

このように，柱梁接合部においては，接合部の終局モーメント $M_{j u}$ は, 軸力 $N_{j}$ およびせん断力 $V_{j}$ の影響を受けることがわかる。これは, 軸力と曲げモーメントを同時に受ける鉄筋コンクリート柱部材の断 面の終局曲げモーメントと軸力の相互作用と本質的に同じ現象であ る。

\section{4 柱梁接合部の釣合い破壊における軸力・せん断力の影響}

柱梁接合部の釣合いモーメント $M_{j b}$ とは, 主筋が降伏すると同時に コンクリートに圧壊が始まる時の柱梁接合部の終局モーメントのこ とである7)。釣合い破壊時には, 接合部の回転変形の進展とともに引 張鉄筋の引張ひずみの増大が減少に転じることになる。そこで，この 条件を適用して釣合い破壊の条件を定量化する。

一定の軸力 $N_{j}$ およびせん断力 $V_{j}$ が作用する条件下において, 柱梁 接合部の釣合いモーメント $M_{j b}$ に及ぼす影響を評価する。接合部 I の 場合には, 文献 7 に示した釣合い破壊の条件と同じ考え方を適用して, 釣合い破壞の条件式は,

$$
T_{y}+\frac{1}{2} N_{j}-\frac{1}{2} V_{j}=\frac{1}{2} g b D \beta_{1} \beta_{3} f_{c}^{\prime} \quad \text { ( 接合部 I ) }
$$

で与えられる。これは，図 5 に示したように，主筋の交差する位置が 中立軸 $\mathbf{G}^{\prime} \mathbf{H}^{\prime}$ および $\mathbf{E} \mathbf{F}^{\prime}$ 上となる条件から導かれる。ここに， $\beta_{1}$ は, 断面の曲げ理論において用いられるコンクリートのストレスブロッ クにおける, ストレスブロックの高さと中立軸から圧縮縁までの距離 の比を表す係数である。この関係を, 式 (7) に代入して, 次の式が得 られる。

$$
\begin{aligned}
M_{j b}= & \frac{1}{2} g^{2} b D^{2} \beta_{1} \beta_{3} f_{c}^{\prime}\left(1-\frac{\beta_{1}}{2}\right)+\frac{1}{2} D N_{j}(1-g)+\frac{1}{2} D V_{j}(1+g) \\
& -\frac{1}{4} D \frac{\left(N_{j}+V_{j}\right)^{2}}{b D \beta_{3} f_{c}^{\prime}}
\end{aligned}
$$

このことから，接合部 I の場合の釣合いモーメントは，主筋間隔比 $g$ の自乗， $b D^{2}$, および，コンクリートの圧縮強度に比例することが わかる。従来の耐震設計においては, 主筋が降伏しないで発生する接 合部のせん断破壊時の強度は, コンクリートの圧縮強度に接合部の水

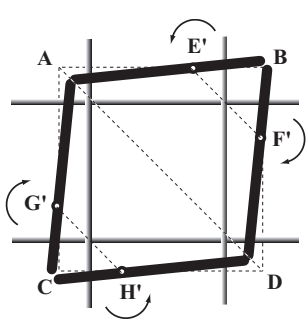

接合部 I の釣合い破壊

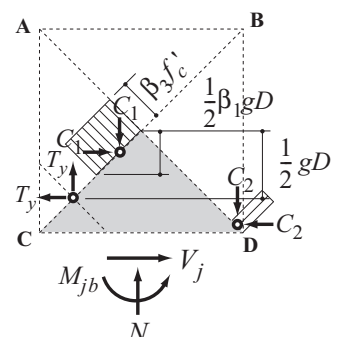

$T_{y}=\frac{1}{2} g b D \beta_{1} \beta_{3} f_{c}^{\prime}-\frac{1}{2} N_{j}+\frac{1}{2} V_{j}$

$C_{1}=\frac{1}{2} g b D \beta_{1} \beta_{3} f_{c}^{\prime}$

$C_{2}=\frac{1}{2} N_{j}+\frac{1}{2} V_{j}$



接合部 II の釣合い破壊

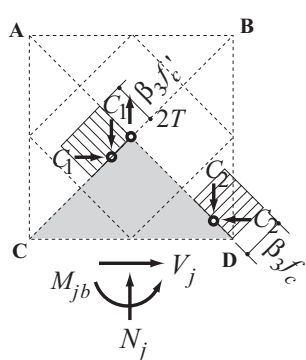

$2 T_{y}=\frac{1}{2} b D \beta_{1} \beta_{3} f_{c}^{\prime}-N_{j}$ $C_{1}=\frac{1}{4} b D \beta_{1} \beta_{3} f_{c}^{\prime}-\frac{1}{2} V_{j}$ $C_{2}=\frac{1}{4} b D \beta_{1} \beta_{3} f_{c}^{\prime}+\frac{1}{2} V_{j}$

$M_{j b} \cong \frac{1}{4} b D^{2} \beta_{1} \beta_{3} f_{c}^{\prime}\left(1-\frac{\beta_{1}}{2}\right)+\frac{1}{2} D V_{j}$

図 5 釣合い破壊
平面積を乗じたものと密接に関係するものとされてきたが, 本理論に おいては, これに加えて, 式(13)に示されているように, 主筋間隔比 $g$ が極めて大きな影響因子であることが示されている。

また, 軸力 $N_{j}$ およびせん断力 $V_{j}$ をゼロとおいた場合の柱梁接合部 の釣合いモーメントに対する釣り合いモーメントの増加分 $\Delta M_{j b}$ は, 式(13)の第 2 項以下の部分であり近似的に,

$$
\left.\Delta M_{j b} \cong \frac{1}{2} D N_{j}(1-g)+\frac{1}{2} D V_{j}(1+g) \quad \text { ( 接合部 } \mathrm{I}\right)
$$

で表わされる。このことから，柱梁接合部が主筋降伏前にコンクリー トが圧壊して決まる最大モーメントの増加分 $\Delta M_{j b}$ に及ぼす軸力 $N_{j}$ の 影響は, 主筋間隔比 $g$ が 1 に近くなるほど, 小さくなることがわかる。 これは, 式 (14) より軸力 $N_{j}$ の項に係数 $(1-g)$ が乗じられているため である。これが意味することは，主筋降伏前に接合部破壊を起こすよ うに計画された実験においては，柱梁接合部の強度に及ぼす接合部横 補強筋量, 柱梁の主筋量および柱の軸力の影響は小さいという実現象 と対応しているものと解釈することができる。それに対して，部材に 作用するせん断力 $V_{j}$ は，常に釣合いモーメントを増大させる効果が あると解釈することができる。 
接合部 II の場合には, 釣合いモーメント破壊の条件は, 図5に示さ れるように,

$$
T_{y}+\frac{1}{2} N_{j}=\frac{1}{4} b D \beta_{1} \beta_{3} f_{c}^{\prime} \quad(\text { 接合部 II })
$$

となる。よって式(15)を式 (8) に代入して整理すれば, 釣合いモーメ ントは, 次の式として得られる。

$$
M_{j b}=\frac{1}{4} b D^{2} \beta_{1} \beta_{3} f_{c}^{\prime}\left(1-\frac{\beta_{1}}{2}\right)+\frac{1}{2} D V_{j}\left(1-\frac{V_{j}}{b D \beta_{3} f_{c}^{\prime}}\right) \quad \text { （接合部 II ) }
$$

よって, 接合部 II の場合に, 軸力 $N_{j}$ およびせん断力 $V_{j}$ をゼロとし た時の釣合いモーメントに対する釣合いモーメントの増加分 $\Delta M_{j b}$ は, 近似的に,

$$
\Delta M_{j b} \cong \frac{1}{2} D V_{j} \quad \text { （接合部 II ） }
$$

となる。式 (17) は，接合部 II において，釣合いモーメントは，せん 断力 $V_{j}$ によりのみ増大し, 軸力 $N_{j}$ の影響は受けないことを示して いる。

\section{5 柱梁接合部の限界補強量}

接合部 Iにおいて, 釣合い破壊を起こさない条件は, 式 (12) を変形 して,

$$
T_{y}-\frac{1}{2} V_{j}+\frac{1}{2} N_{j}<\frac{1}{2} g b D \beta_{1} \beta_{3} f_{c}^{\prime}
$$

( 接合部 I )

となり，接合部 II において，釣合い破壞を起こさない条件は，式 (15) を変形して,

$$
T_{y}+\frac{1}{2} N_{j}<\frac{1}{4} b D \beta_{1} \beta_{3} f_{c}^{\prime}
$$

( 接合部 II )

となる。これらの式の右辺を, 以下, 限界補強量と定義する。すなわ ち, 釣合い破壊を起こさない条件は, 主筋の降伏時の応力 $T_{y}$, 部材 端から作用するせん断力 $V_{j}$ および接合部を拘束する応力 $N_{j}$ の組み 合わせで表される等価な補強量が, 限界補強量より小さくなければな らないものとして規定することができる。限界補強量は, 接合部の形 状 $b D$, 主筋間隔比 $g$, ストレスブロックの係数 $\beta_{1} \beta_{3}$, コンクリート の圧縮強度で決まる。接合部 Iでは, 主筋間隔比 $g$ が大きいほど, 限 界補強量は小さくなるのに対して, 接合部 II の場合には, 限界補強量 は主筋間隔比 $g$ によらず一定値となる。

\section{3. 梁降伏型に設計された柱梁接合部の終局モーメント \\ 3. 1 梁降伏型の柱梁接合部}

文献 7 および, 本論文の前節までの議論は, 柱梁の通し主筋がいず れも同時に降伏するか，もしくは，両方が降伏しない場合の柱梁接合 部の接合部の性能に関するものであった。現実的な骨組構造の建築物
の柱梁接合部においては, 柱断面と梁断面の曲げ補強量が等しいとは 限らない。最近の鉄筋コンクリートモーメント骨組の耐震設計では, 安定した全体降伏機構を確保する必要性から, 柱端部に曲げ降伏ヒン ジを形成することのないように, 梁曲げ終局モーメントに対して, 柱 の曲げ終局モーメントに一定割合の余裕を持たせるように設計する 場合がある。そこで, 以下，一方の部材が先に降伏し（以下，先に降 伏する部材を「降伏部材」という）他方の部材が降伏しない（以下, 「非降伏部材」という）として，このような柱梁接合部についての柱 梁接合部の終局モーメントを検討する。

梁曲げ降伏型に設計された柱梁接合部であっても, 最初に梁主筋が 降伏する時の接合部モーメントは, 式 (6) になると考えられる。ただ し，その時点では柱主筋は未降伏である。そこからさらに接合部の変 形が増大した場合について考察する。梁主筋の引張り歪は増大するが 既に降伏棚に入ってしまっているため, 梁主筋の応力は降伏点を保持 したままで梁主筋の塑性変形が増大する。一方で, 柱主筋の引張り歪 も増大するが柱主筋は依然として線形弾性範囲にあるため, 接合部の 変形増大は抑止される。その結果柱主筋の応力は一様に引張側にシフ トして, 柱梁接合部の膨張を拘束しながら, 柱主筋の応力の増大が起 こる。
3. 2 非降伏部材の曲げ余裕度が柱梁接合部の終局モーメントに及 ぼす影響

そこで, 降伏部材 (ここでは梁) の主筋の応力は一定に保たれ，か つ, 非降伏部材（ここでは柱）の主筋は弾性のままで, 降伏部材の主 筋の降伏応力 $T_{y}$ から一様に $T_{y}+\Delta T$ に増大した状態を想定する。以 下， $\Delta T$ だけ主筋応力が引張側にシフトするので, $\Delta T$ を「引張シ フト」と呼ぶ。この条件の下での柱梁接合部の終局モーメント $M_{j u}$ を導いて, 非降伏部材の主筋応力の引張シフト $\Delta T$ が, 接合部の終 局モーメント $M_{j u}$ をどのように変化させるか考える。引張シフト $\Delta T$ が生じる時の内部応力の変化を, 図 6 のように仮定する。すなわち, 全体の力の釣合いは失われないようにするため, 内部応力はそれ自体 で釣合いを保つように変化するものと仮定する。結果としてコンク リートに生じる反力 $C+\Delta C$ は, もはや柱梁接合部の対角線に直交は しないが, $\Delta C$ は, $C$ より相対的に小さいので, 柱梁接合部の対角 線に直交しない成分は直応力下のせん断力により伝達され得るもの と仮定する。なお，この仮定は，断面の曲げ理論の適用において部材 に生じるせん断力の存在を無視できるのと同じであり, 妥当な仮定で ある。

これまでと同様の方法により, 力の釣合いから, 圧縮合力の位置を 表す, $j_{1}, j_{2}$ を求めて, 仮想変位の原理を用いて, 接合部の抵抗モ一 メント $M_{j}$ を算出すれば, 式 $(20)$ を得ることができる。

$$
\begin{aligned}
M_{j}= & D T\left\{\alpha+g(1-\alpha)-\frac{\left(1+\alpha^{2}\right) T_{y}}{b D \beta_{3} f_{c}^{\prime}}\right\} \\
& +\frac{1}{2} D \Delta T\left\{1-\frac{2(1+\alpha) T_{y}+\Delta T}{b D \beta_{3} f_{c}^{\prime}}\right\}
\end{aligned}
$$



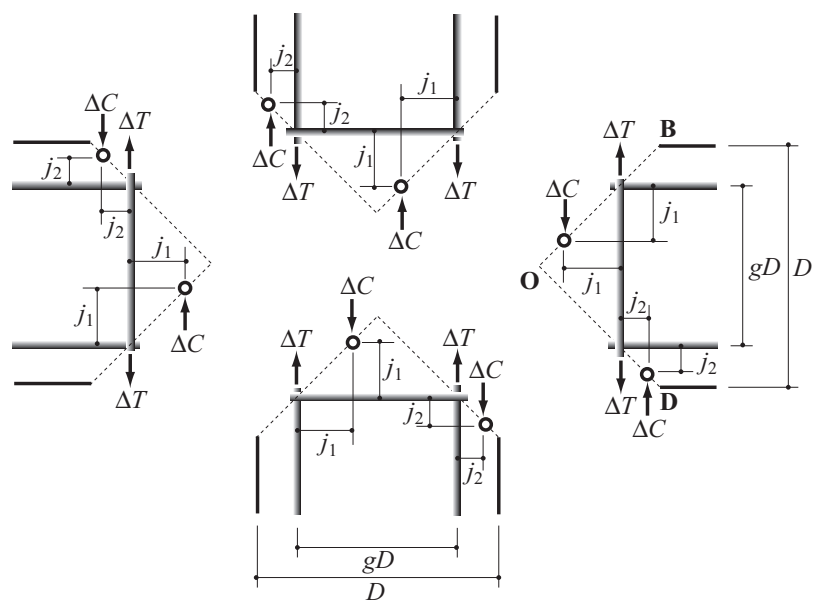

図 6 十字型柱梁接合部の内部応力とその作用位置

梁降伏が最初に起こった時点の接合部モーメント $M_{j}$ すなわち, $\Delta T$ がゼロの時の值を基準として, 非降伏部材の主筋の応力増分 $\Delta T$ が発 生したことによる柱梁接合部のモーメント $M_{j}$ の変化量, すなわち, 増分 $\Delta M_{j}$ は, 式 (20)の第 2 項であり,

$$
\Delta M_{j}=\frac{1}{2} D \Delta T\left\{1-\frac{2(1+\alpha) T_{y}+\Delta T}{b D \beta_{3} f_{c}^{\prime}}\right\} \cong \frac{1}{2} D \Delta T
$$

となる。このことから, 非降伏部材の引張主筋の引張シフト $\Delta T$ は, 柱梁接合部の抵抗モーメントを増大させ，その量は近似的に式 (21) で 表すことができる。

したがって, 非降伏部材の主筋量もしくは主筋の降伏強度を高めて 非降伏部材の曲げ強度の降伏部材の曲げ強度に対する余裕を増加さ せれば，梁主筋降伏後も接合部の変形増大を抑えることができる。つ まり，非降伏部材の降伏部材に対する曲げ余裕度が大きいほど，柱梁 接合部の終局曲げモーメントは増大し, 接合部変形が抑止されること が予測される。

3. 3 非降伏部材の軸力増大が柱梁接合部の終局曲げモーメントに 及ぼす影響

次に, 非降伏部材の軸力のみが圧縮側に $\Delta N$ だけ変動した場合の 柱梁接合部の抵抗モーメント $M_{j}$ を考える。柱軸力のみが増えた場 合の柱梁接合部の終局モーメントは, 式 (21) が導びかれたのと同様の 方法で導かれる。すなわち， $\Delta T$ を $\frac{1}{2} \Delta N$ で置き換えてやればよい。 そこで, 非降伏部材の圧縮軸力増大量 $\Delta N$ による柱梁接合部の終局 モーメントの増分は，次式で表され，

$$
\Delta M_{j}=\frac{1}{4} D \Delta N\left\{1-\frac{2(1+\alpha) T_{y}+\frac{1}{2} \Delta N}{b D \beta_{3} f_{c}^{\prime}}\right\} \cong \frac{1}{4} D \Delta N
$$

が成立する。

\section{4. 相互作用における各種因子の等価性}

\section{1 非降伏部材の曲げ強度余裕度と等価な影響因子}

これまでに導いてきた，柱梁接合部に作用する上下左右対称な軸力 $N_{j}$, 上下左右対称なせん断力の影響 $V_{j}$, 非降伏部材の曲げ主筋の引 張力の増分 $\Delta T$, 非降伏部材の圧縮軸力の増分 $\frac{1}{2} \Delta N$ などが, 柱梁接合 部の抵抗モーメントの増分 $\Delta M_{j}$ に及ぼす影響は, その導出過程を考 慮すれば, それらの影響は加算的に評価されることがわかる。つまり， その関係は近似的に,

$$
\Delta M_{j} \cong \frac{1}{2} D\left(C_{j}+V_{j}+\Delta T+\frac{1}{2} \Delta N\right)
$$

と表現することができる。すなわち，式 (23)の各項は，柱梁接合部に 作用する上下左右対称な軸力 $N_{j}$, 上下左右対称な部材せん断力 $V_{j}$, 非降伏部材の曲げ強度の余裕による主筋応力の上昇 $\Delta T$ および, 非降 伏部材の軸力の半分すなわち $\frac{1}{2} \Delta N$ は, 柱梁接合部の抵抗モーメント の上昇に関してそれぞれ同じ量の効果を有するという意味で等価な 影響因子である。

4.2 柱梁接合部の横補強筋・非降伏部材の中段筋 - 直交梁の効果 柱梁接合部の横補強筋や柱接合部を貫通する部材の中段筋は，柱梁 接合部の終局時に柱梁接合部が膨張することを拘束しょうとして引 張降伏し，その反力が柱梁接合部を拘束する応力として受動的な拘束 効果を及ぼす。よって，これらは，非降伏部材の軸力と同様に柱梁接 合部の抵抗モーメントを増大させる。さらに，前節で述べたのと同様 の理由により, 柱梁接合部の横補強筋や中段筋による効果は加算的に 評価でき,

$$
\Delta M_{j} \cong \frac{1}{4} D \Sigma a_{w} f_{w y}+\frac{1}{4} D \Sigma a_{m} f_{m y}
$$

と表せる。また，式 (24) 式は式 (23) に加算することができる。ここ に, $\Sigma a_{w}$ : 接合部横補強筋の断面積の総和, $f_{w y}$ : 横補強筋の降伏点, $\Sigma a_{m}$ : 部材の中段筋の断面積の総和, $f_{m y}$ : 部材の中段筋の降伏点。

接合部に加力方向に直交する方向に接続する直交梁の影響も同じ ように評価される。直交梁の主筋は，2 方向水平力を受けて，直交方 向加力時の曲げ降伏によって梁端部に残留歪が蓄積し, 梁端部に残留 ひび割机が生じるので, 直交梁自体が柱梁接合部の面外方向への膨張 を拘束する効果は小さいと考えられる。しかし，接合部の変形の増大 につ机て，図 7 に示すように，直交梁端部断面においては直交梁主筋 にずれが生じざるを得ない。そのため，それらのダウエル作用によっ て直交梁が受動的な柱梁接合部を拘束する作用が期待できる。なお,

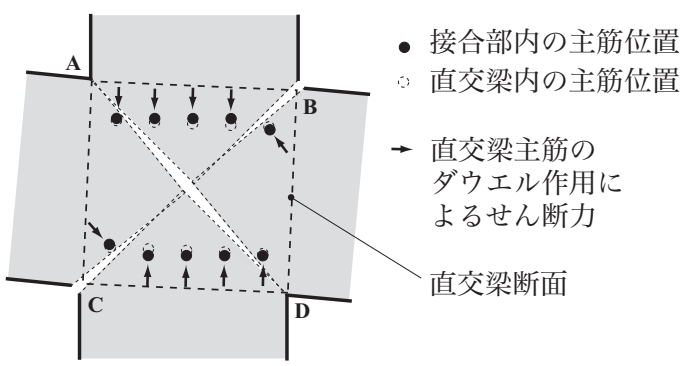

図 7 直交梁主筋のダウエル効果による拘束力発生の機構 
ダウエル効果の特性上，柱梁接合部に大きな変形が生じて初めて拘束 力が生じるので, 接合部の損傷を小さくとどめるための効果は期待で きない。すなわち, 直交梁は, 柱梁接合部の変形と損傷の増大を抑え る効果は期待できないが, 接合部の大変形時には, 接合部終局モーメ ント $M_{j}$ の上昇に寄与する効果は十分に期待できる。ダウエル効果に よる拘束力は, 式 (24) と同様に柱梁接合部の抵抗モーメントを増大さ せる。

\section{5. 柱梁接合部の終局モーメント式の検証}

梁曲げ降伏型に設計され, 静的載荷実験を行った十字型平面柱梁接 合部の試験体 2 体 ${ }^{8}$ ) 9) 10)（図 8）について本理論を適用して終局強度 の解析を行う。試験体・材料の力学特性, 加力方法, 計測方法などの 詳細は, 文献 8) 9) 10) に報告されている。試験体 A1 は, 梁主筋がすべ て引張降伏したにも関わらず，梁の梁曲げ強度が理論值より低下する 現象が見られ，接合部がせん断破壊して大変形で耐力低下が起こって いる。試験体 $\mathrm{C} 1$ は, 試験体 $\mathrm{A} 1$ と同一形状・同一材料・同一配筋で, 直交梁が有無のみが異なる。直交梁端部には, 直交梁の端部における ひび割れを想定し，コンクリート打設時に幅 $1 \mathrm{~mm}$ のスリットを設け ている ${ }^{9)}$

図 8 に, 2 体の試験体の荷重と変形の関係を示す。試験体 $\mathrm{A} 1$ は, 2 段筋の降伏直後に最大耐力に達しており, 梁主筋の降伏により強度が 決まっている。また，柱曲げ強度は梁曲げ強度に対して $25 \%$ 〜 $30 \%$ の余裕を持たせて設計してあるが, 最大強度時には柱主筋の降伏も発 生した。梁曲げ終局時のせん断力を実験值と計算值で比較すると試験 体 A1 の実験值は，曲げ強度の計算値の $90 \%$ ～93\% 程度となってい る。現行の設計基準や既往の研究にはこのような強度低下の発生を合 理的に説明できるものはない。

本論文の式 (7) を用いて, 実験值と解析值の比較を行い本理論の検 証を行う。検証に当たっては，次の試験体と材料の諸元を用いる。柱 は断面が 300mm 角の正方形で, 主筋は 16-D13 で（降伏点強度は 327MPa) であり, 梁も断面が 300mm 角の正方形で, 主筋は 16-D13 で (降伏点強度は $456 \mathrm{MPa}$ ) である。コンクリート強度はシリンダーの圧 縮試験で得られた $28.3 \mathrm{MPa}$ とする。柱軸力は一定で $216 \mathrm{kN}$ の実験值 を用いる。主筋間隔比 $g$ は, 梁が 2 段配筋であるため, 引張鉄筋と圧 縮鉄筋のそれぞれの重心間距離から算定するものとする。さらに，柱 と梁で $g$ が異なる值であるため, それらの平均值である 0.7 を用いる。 コンクリートのストレスブロックの形状を表す係数 $\beta_{3}$ は, ACI 基準 に準じて， 0.85 を用いる。さらに，式(7) 中のせん断力 $V_{j}$ は, 接合部 の終局時のモーメント $M_{j u}$ の時の柱と梁のせん断力の平均值を採用す るものとする。式 (7) は, 右辺に $V_{j}$ が含まれ $M_{j u}$ に関する陽な式と なっていないので, 数值解法により軸力 $N_{j}$ と層せん断力の関係を求 める。その結果を図 9 に示した。柱梁接合部の拘束による補強効果 $N_{j}$ が増大するほど柱梁接合部の終局強度は増大する。図 9 では, 曲げ理 論による梁断面の曲げ降伏強度の計算值から求めた層せん断力も示 している。軸力 $N_{j}$ が $125 \mathrm{kN}$ あたりを境に, 2 種類の強度の計算值は 逆転している。軸力 $N_{j}$ が小さいと柱梁接合部の強度は, 接合部の終 局強度で決定され, 大きいと梁断面の曲げ強度により決定されること
が予測される。

次に，これを実験と比較する。試験体及び材料の諸元より，式 (7) におけるそれぞれの定数の実際の值は， $T_{y}$ が $405 \mathrm{kN}$ となる。また， 柱の主筋の引張シフト $\Delta T$ は $-179 \mathrm{kN}$, 柱の軸力項 $\Delta N$ は, 軸力に柱 中段筋が引張降伏する時の力を加えて $216+274=490 \mathrm{kN}$, 接合部 補強筋の拘束力は, $61 \mathrm{kN}$ となる。よって, これらと等価な軸力 $N_{j}$ は, $0.5 \times(490+61)-179=97 \mathrm{kN}$ となる。これらの值を代入すると, 試験 体 $\mathrm{A} 1$ の柱梁接合部の終局モーメント $M_{j u}$ に基づく層せん断力の計算 值は，130 kN となる (図 9 参照)。実験值は，127kN と良い対応が得 られている。

一方，試験体 $\mathrm{C} 1$ は直交梁を有する。しかし，梁端部にスリットが あるため, 直交梁が接合部の面外方向への膨張する効果はない。そこ

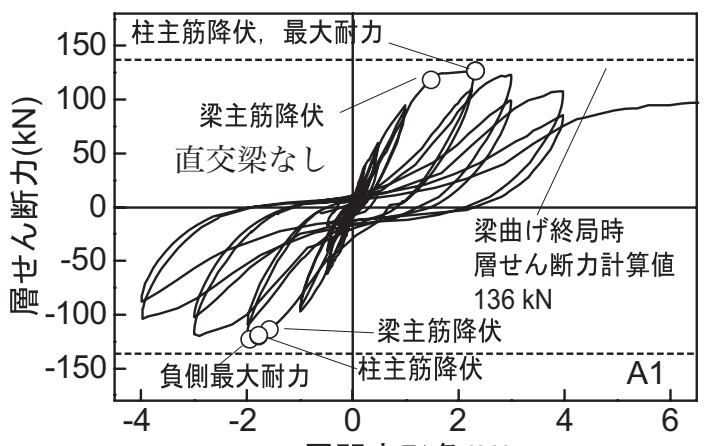

層間変形角 $(\%)$

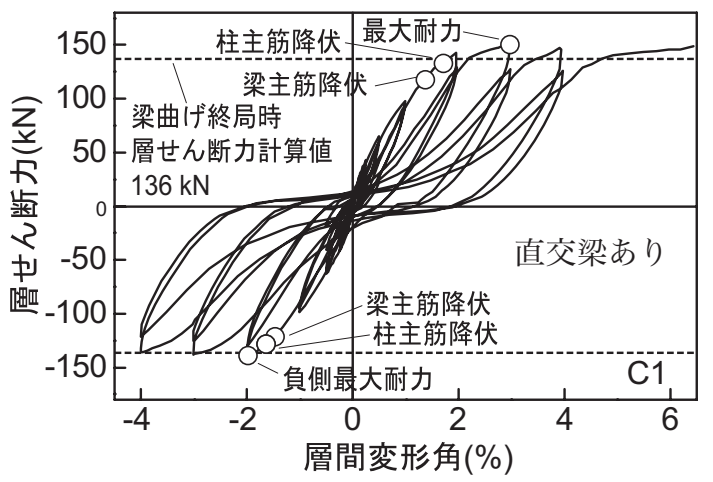

図 8 試験体 $\mathrm{A} 1$ と $\mathrm{C} 1$ の荷重変形関係（文献 9)

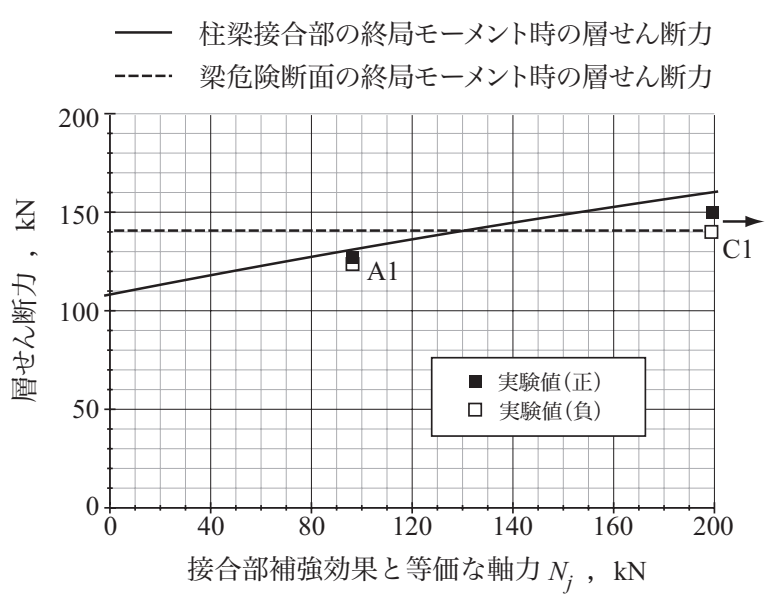

図 9 最大層せん断力の実験值と解析値の比較 
で，直交梁主筋（片側 16-D13）のダウエル効果による拘束力を軸力 $N_{j}$ に加算して算定する。直交梁主筋 1 本あたりのせん断強度を耐震改修 設計指針 ${ }^{11)}$ の接着系アンカーのせん断強度式を準用して求めると $30.3 \mathrm{kN}$ となる。よって, ダウエル効果による拘束力と等価な軸力 $N_{j}$ は, $0.5 \times 30.3 \mathrm{kN} \times 16=242 \mathrm{kN}$ として求められ, 図 9 における接合 部補強効果の総和は $N_{j}=97+242=339 \mathrm{kN}$ となる。この值は図 9 の横 軸の右端を大きく越えている。よって, 試験体 $\mathrm{C} 1$ では, 直交梁の効 果によって, 接合部の曲げ終局モーメントが増大して, 梁危険断面の 終局曲げモーメントを上回るので, 梁端部危険断面で架構の終局強度 が決まることとなる。実験值は，150kN（正），129kN（負）であり， 計算值の $140 \mathrm{kN}$ と概㸚対応している。しかし, ダウエル作用によって 拘束効果が発揮されるのは, 接合部に大きな変形が生じてからとなる ため, 文献 7 の図 1 に示したように, 試験体 $\mathrm{C} 1$ の接合部には大きな 斜めひび割れを含む損傷が生じているものと考えられる。よって本解 析によって, 試験体 $\mathrm{A} 1$ のように曲げ強度の計算值に達しないような 現象の発生の原因が説明できたと考えられる。また，たとえ主筋が降 伏しても接合部破壊が発生するという本理論の妥当性が, 検証された ものといえる。従来の研究では, 梁曲げ降伏が起こりながら強度が梁 曲げ降伏強度に達しないという実験を報告した研究はあまり見られ ない。この理由は, 従来の実験では, 試験体が柱の曲げ強度に余裕を 持たせて設計されることがほとんどであって，接合部補強効果が大き かったので, 試験体 $\mathrm{A} 1$ のような現象が見られなかったと考えられる。 文献 8) の試験体 A1 では, 柱の曲げ強度の梁の曲げ強度に対する比の 值が 1.3 と小さいこと, 梁が 2 段主筋のため主筋間隔比 $g$ が小さかっ たことが, 柱梁接合部の終局モーメントを大きく低下させたと推定さ れる。

\section{6. 結論}

力の釣合い条件, 終局時のコンクリートの破壊条件と鉄筋の降伏条 件を考慮した理論式に基づいて, 次の定量的評価式が導かれることを 示した。

柱もしくは梁の主筋が降伏する場合の, 柱梁接合部の終局モーメン ト式を導出した。接合部モーメントは, 部材せい, 主筋量, 鉄筋の材 料強度, 主筋の間隔比の影響が主要因子であり, さらに, 終局モーメ ントは, 柱梁接合部に働く軸力や部材端から接合部に作用するせん断 力によっても変動することを示した。

また，主筋が降伏すると同時にコンクリートが終局状態に達する時 の柱梁接合部の釣合いモーメントを導出した。釣合いモーメントは, 終局モーメントと同様に, 部材せい, 主筋量, 鉄筋の材料強度, 主筋 の間隔比の影響の影響を受けるが，主筋間隔比が 1.0 に近くなると, 柱梁接合部を拘束する軸力の影響を受けなくなることが示された。

また, 曲げ降伏先行型で設計される柱梁接合部においては, 柱梁接 合部の終局曲げモーメントは, 柱の梁に対する曲げ強度の余裕度の増 加, 接合部内横補強筋量による面内拘束, 直交梁主筋のダウエル効果 による面内拘束によっても増大することを示し, これらの効果は加算 される性質があり，柱梁から接合部に作用する軸力と等価な効果を有 することが示された。
提案された理論式を，柱梁接合部が柱と梁の主筋が降伏すると同時 に接合部破壊が始まる現象が見られた試験体に適用して, 最大強度が 実験結果と良く一致することが示され，理論の妥当性が検証された。

\section{7. 今後の課題と将来の展望}

本論文においては，平面十字形柱梁接合部に外力として偶力と軸 力・せん断力が作用した場合の，柱梁接合部の終局モーメントと釣合 いモーメントの数式解および，梁降伏が柱降伏に先行する場合，接合 部補強筋や柱に中段筋が存在する場合などの影響の効果について論 ずることができた。しかし, 柱梁接合部の力学モデルの開発の目的は, 柱梁接合部の強度を求める強度式を導くことではない。具体的な目標 性能として，(1) 接続する部材が曲げ理論で推定される剛性と曲げ強 度を確実に発揮されるようにすること，(2) 柱梁接合部に損傷が集中 しないように制御するための性能設計法に応用することにあるが, 本 論文においては, 紙面の都合上そこまで示すことはできなかった。こ こで導かれた柱梁接合部の終局モーメントや釣合いモーメントおよ び限界補強量を使ってどのような性能設計のための設計規範とする ことが実用的で望ましいかについて, さらに検討を進める必要があ る。

\section{参考文献}

1) M. R. Ehsani and J. K. Wight : Exterior Reinforced Concrete Beam-to-Column Connections Subjected to Earthquake-Type Loading, ACI Journal, Vol. 82, No. 4, pp. 492-499, July-August 1985.

2) 角徹三, 浅草肇, 青木正美 : 鉄筋コンクート柱・はり外部接合部を含む架構 の勒性評価, 日本建築学会構造系論文報告集, 第 401 号, pp. 87-96, 1989. 7.

3) 草苅敏夫, 城攻 : 実験的資料に基づく $\mathrm{RC}$ 造内部柱梁接合部のせん断耐力 評価に関する検討，コンクリート工学論文集，第 9 巻，第 1 号，pp. 35-45, 1998.

4) 森田真司, 北山和宏, 小山明男, 細野具貴 : RC 内柱梁接合部のせん断強 度に及ぼす梁主筋付着と柱軸力の影響，コンクリート工学年次論文報告 集, Vol. 21, No.3, pp. 679-684, 1999.6.

5) 細矢博, 小河義郎, 浅野芳伸 : 柱主筋位置が柱梁接合部の構造性能に与え る影響，コンクリート工学年次論文集，Vol. 24，No. 2, pp. 427-432， 2002. 6.

6) S. Hakuto, R. Park and H. Tanaka : Effect of Deterioration of Bond of Beam Bars Passing through Interior Beam-Column Joints on Flexural Strength and Ductility, ACI Structural Journal, Vol. 96, No. 6, pp. 858-864, Sept.-Oct. 1999.

7) 塩原等 : 鉄筋コンクリート柱梁接合部 : 見逃された破壊機構, 日本建築学 会構造系論文集, 第 73 巻, 第 631 号, pp. 1641-1648, 2008.9.

8) 塩原等, 楠原文雄 : 鉄筋コンクリート造柱梁接合部の損傷が梁曲げ強度に 及ぼす影響，コンクリート工学年次論文集，Vol. 29，No. 3，pp. 247-252， 2007. 7 .

9) 楠原文雄, 塩原等 : 多軸複合応力を受ける鉄筋コンクリート造柱梁接合部 の復元力特性と損傷特性, コンクリート工学年次論文集, Vol. 29, No. 3, pp. 235-240, 2007. 7 .

10）塩原等, 岡田浩一, 楠原文雄 : 多軸複合応力を受ける鉄筋コンクリート造 柱梁接合部のベンチマークテスト, 日本コンクリート工学協会年次論文 集, Vol. 27, No. 2, pp.421-425, 2005. 6.

11) 日本建築防災協会 : 2001 年改訂版既存鉄筋コンクリート造建築物の耐震 改修設計指針同解説，2001. 10.

（2008年 6 月 8 日原稿受理，2008年10月 1 日採用決定） 